\title{
Employee-Management Cooperation: The Key to Employee Productivity
}

\author{
M. A. Akkas, Anannay Chakma, Mohammad Ikbal Hossain \\ Dhaka University, Dhaka, Bangladesh
}

\begin{abstract}
This paper aims at examining the importance of cordial and high-level cooperation between management and employees, as identical partners in industrial advancement and progress. There is a legislative obligation to form a participative committee at the industrial enterprises in Bangladesh to achieve labor-management cooperation, but the majority of the executives mainly in the private sector, have ill-treated this prerequisite of regulation. Based on an interview with a good number of respondents (managers, union leaders, experts, and political leaders), the study has attempted to identify the obstacles that stand in the way of cohesive cooperation between these two parties. The important factors deterring collaboration according to the respondents are: mutual mistrust between management and labor, class distinction between managers and employees, labor disputes, politicization of labor unions resulting in intra- and inter-union rivalries, worker's backwardness, problem of determination of a collective bargaining agent, and infringement of labor laws, among others. Because of these factors, this committee has not yielded effective results. The prevailing climate is not encouraging cooperation, rather inhibiting the same. Finally, some suggestions such as top management support and commitment, confidence in people, employment security, trust, adequate information, reward, friendly working environment, acceptance of change, interaction between managers and employees, and timely feedback have been recommended which may help create congenial labor-management cooperation at the plant level as a means of establishing industrial peace and achieving higher productivity.
\end{abstract}

Keywords: labor-management cooperation, politicization of labor union, collective bargaining, participative committee

The concept of employee-management cooperation is relatively new but very attractive and found to be effective in the Western countries and Japan. Currently, it has gained more popularity in the changed economic and business world characterized by stiff foreign competition, changes in technology and deregulation. These economic and social trends certainly favor cooperative efforts in business and industrial fields. In view of these changes, accommodation of labor and management to each other's needs (win-win bargaining) is more appropriate than the old adversarial win-lose approach. It is of much importance to establish a cooperative relationship between management and labor in order to succeed in the competitive business world. Management experts are of the view that by accommodating one another's need, management and labor can

Corresponding author: M. A. Akkas, M.Com, MBA, professor, Department of Management, Dhaka University, Dhaka, Bangladesh; research fields: human resource management and knowledge management. E-mail: prof.akkas@gmail.com.

Anannay Chakma, MBA, lecturer, Department of Management, Dhaka University, Dhaka, Bangladesh; research field: human resource management. E-mail: anannayductg@gmail.com.

Mohammad Ikbal Hossain, MBA (HRM), research associate, Dhaka University, Dhaka, Bangladesh; research fields: human resource management and corporate governance. E-mail: ikbalsmn@gmail.com. 
achieve two goals at once: increase productivity and improve quality of work life. Empirical studies suggest that productivity and quality of work life go hand in hand (Cascio, 1995; Davis, 1990). In the current climate of wants and needs, there is no other alternative. The win-lose approach must change if enterprises are to remain competitive in the international marketplace. Through cooperation, both parties can replace reactive measures with proactive approaches. Proactive efforts benefit the union and the company by saving time and expenses.

The goals of employee-management cooperation are to increase productivity, promote industrial democracy, avoid conflict, and obtain benefits for both parties, not to bargain over the division or distribution of gains. Each party has to serve its own interest by cooperating with others. By working together, management and workers can find ways to lower costs and provide superior value to customers. These savings can mean higher profits for the company and better contract for the union. Human relations and behavioral experts strongly feel that productivity or industrial progress depends on a cordial and sound union-management relationship. Both management and workers are the equal partners of industrial progress and prosperity. Gatchalia (2012) argues that the term "Workplace cooperation is now understood as a broad concept connoting mutual commitment between labor and management to working together and working smarter". Specifically, its goal is to develop an ideal situation where management and workers are full partners in identifying problems in the workplace, crafting solutions to those problems, and implementing the agreed-upon solutions. The idea is that greater cooperation between labor and management on matters of mutual concern can create a more satisfying and productive workplace. The process involves employee participation in day-to-day decision-making that affects their jobs. The structures and procedures enable the partners to redesign work to encourage group problem-solving, open information sharing, teamwork, and skill development.

Many experts believe that people are the key to productivity. The excellent firms in the USA, according to Peters and Waterman (1982), also encourage productivity via people. Productivity through people does not involve too much cost. Akio Morita (1986), the pioneer of the big Sony Corporation, rightly says that: "Assets make things possible, but people make things happen". It is people that make the difference between success and failure.

Drucker (1994) argues that union leaders have a tendency to resist changes. In his opinion, only voluntary and cordial cooperation can reduce workers' resistance to change when they know that changes will not cause any inconvenience to them. Both employees and managers are concerned about organization and workplace productivity, because without it, management will not be able to provide unionized workers with high wages, benefits, and job security. To address these economic and productivity issues, union and management have entered into a number of joint cooperative programs such as quality circles and quality improvement teams, formal employee-management forums and joint committees, quality of working life activities, shared governance (co-determination councils), and employee involvement initiatives including self-managed teams. Employee-management forums are formal vehicles for bringing labor and management together under a spirit of cooperation and partnership. Darby (2006) surveyed 55 employers and 66 unions in Canada about labor-management committees. She concluded that joint committees have the potential to improve communication, result in fewer grievances, and enhance employee-management relations.

\section{Methodology}

This paper is based on both primary and secondary data. A total of 100 respondents were selected randomly from 10 different types of organizations. Respondents consist of labor leaders, workers, managers, 
and employee directors. They were asked to state three most important factors affecting the employee-management cooperation of their enterprises. Ten respondents did not give any responses. A total of 270 responses from 90 respondents were obtained. With a view to getting a fair picture of the overall situation of labor-management cooperation, in addition to the question-answer method of the sample survey, the author had informal discussions with two of the respondents of each category. Relevant labor laws, books, and journals were also examined to know about employee-management cooperation in Bangladesh.

\section{Improving Productivity Through Cooperative Employee-Management Relations}

Under this circumstance, fostering union-management cooperation to solve the problem of organizational ineffectiveness cannot be ignored. Productivity improvement is the only way of addressing the challenge of globalization, which is characterized by international competition, deregulation, and automation. It also determines people's standards of living within a particular country. Thus, the citizens of the highly productive country are likely to have notably higher standards of living than the citizens of a country with low productivity. Improved productivity mitigates the workers' demand for higher wages and employers' demand for higher return on investment. How does a business or industry improve its productivity? Numerous specific suggestions made by the experts for improving productivity generally fall into two broad categories: improving research and development (R\&D) operation and increasing employee cooperation through participation (Pfeffer, 1998).

$R \& D$ activities are expensive and risky, but it does not mean that $R \& D$ is less important. The reality is that the poor developing countries like Bangladesh cannot easily increase $R \& D$ activities due to resource constraints (Akkas, 1994). But these countries can easily modify and change the existing management practices, particularly modify and change human resources management to enhance quality and productivity. Drucker (1994) rightly says, "Japanese firms succeed in the competitive business world by establishing a cooperative relationship between management and employee". Now it is important to explain the concept of employee-management cooperation.

\section{Concept of Employee-Management Cooperation}

Employee-management cooperation is a state of relations where employee and management work together to accomplish certain goals using mutually acceptable means. It is the outcome of a continuous process of enhancing mutual trust and respecting through sharing information, discussion, consultation, and negotiation. It is a scheme of workers' participation process on matters not covered by collective bargaining agreements. It should be fully integrated into organizational culture. People are the greatest asset of an organization and each individual has the potential to strengthen and change the organization. Good ideas are not reserved for management only a wide range of topics exist when employees and managers are recognized and addressed by all the parties, the potential for better solution exist.

Employee-management cooperation is often confused with collective bargaining, although these two are not the same or identical. Employee-management cooperation, as viewed by Weinberg (1988), is not an alternative to free collective bargaining, rather it extends collective bargaining beyond its traditional limits that is to deal with issues of mutual interest without impairing either party's bargaining strength. Collective bargaining deals with matters of the divergence of interests, while labor-management cooperation deals with matters of common interest. The underlying principle is that there are many matters of common concerns to managers and workers, which can best be handled by cooperating. Employee-management cooperation is not a 
replacement for collective bargaining (Weihrich, 1996). Instead, it should be viewed as a supplement to collective bargaining. Employee-management cooperation can be understood as any mode of bargaining or joint discussion in which the objective is to improve the well-being of both parties (Cooke, 1990; Kochan \& Osterman, 1994).

Employee-management cooperation can occur by setting up an Employee Management Council (EMC). EMC is a voluntary association of representatives of workers and management who meet to identify and resolve issues of common interest (Gatchalia, 2012). These issues are normally separated from and outside of the scope of a contract or collective bargaining agreement if there is a union. A number of obstacles can be identified which prevent joint cooperative efforts between management and labor (Pfeffer, 1998). The main barriers are as follows:

(1) Managers may not like to accept the legitimacy of the union;

(2) Union officials are ideologically found to oppose, not to cooperate with management;

(3) Internal union politics may hinder forming cooperative ventures with management;

(4) The fear among union members that cooperation with management may lead to the erosion of the benefits that they have worked so hard to attain;

(5) Critics also argue that innovative workplace practices undermine union power by co-opting employees by forcing the alignment of employee interests with those of management;

(6) In some instances, employee-management committees or employee involvement forums may be considered unlawful if they are deemed to have been "set-up" by management as a means of usurping union prerogative.

\section{Employee-Management Cooperation Scenario in Bangladesh}

We are living in an interdependent world. It is a reality that we live in a borderless economy. We cannot avoid it. Unfortunately, the business firms of all the countries do not have equal access to this free world trade. It is productivity that makes the difference between success and failure. The developed countries are winning this trade war due to their higher productivity growth. They are almost monopolizing the benefits of free trade. The business organizations of poor countries like Bangladesh are facing big challenges unleashed by the globalization. Many industrial units are being closed down. Many people are losing jobs and thus living in abject poverty. Consequently, many young and bright people are leaving the country to change their lots. The country is lagging far behind in the race of employee productivity. Because of fierce international competition, worldwide customers are now able to choose among several international competitors.

Employee-management relations can be cooperative or they can be adversarial. As mentioned earlier, cooperative employee-management relations are a definite asset for a firm, especially for one in a competitive situation. Unfortunately, an adversarial relationship between management and organized labor has been prevailing in the country for the last few decades. Adversarial relations make it nearly impossible to implement significant and lasting change that will benefit customers. These poor relations between union and management may be responsible for poor industrial performance. Adversarial situations can be marked by a number of confrontations between management and labor in the country. Workers are highly politicized and fragmented. They are more loyal to the party to which they belong and less to the organization. Anderson, Hossain, and Sahota (1991) maintain that unions act more as political entities, not as economic agents in Bangladesh. Every political party has its own labor front (Akkas, 2001b). They often engaged in inter-union rivalries and conflicts. 
Most of the time, the problem starts when a union affiliated with one political party tries to overthrow the existing Collective Bargaining Agent (CBA) affiliated with a different political party. This is done when the mentor - political party gets elected to hold state power. Management cannot take proper action against these unions having political affiliation. All these non-cooperative activities may result in decline of output and employment (Mondal, 1998). Now the relevant questions are: What are the barriers that stand in the way of the effective union-management cooperation in the country like Bangladesh? What are the ways out? This paper addresses these burning issues in the context of Bangladesh.

\section{Impediments Standing in the Way of Employee-Management Cooperation in Bangladesh}

The reasons for lack of cooperation identified by the managers and union leaders are many and varied in nature. Both parties have a tendency to claim themselves fair and honest and put blame on another party. Among the most important of these barriers are the following:

(1) Most of the managers are reluctant to give up their exclusive control over organizational policy and strategy. They think that decision-making is their job, not the union or workers'. Managers think that the participation committee may threaten their prerogatives considerably. The decision-making authority in Bangladeshi organizations is highly centralized (Akkas, 2001a);

(2) Managers are reluctant to take the risk involved in depending on others. They do not trust the subordinates, and consequently, they do not like to share power with the workers;

(3) Managers bring allegations against the union for their political affiliation. According to managers, politicization of union is the root of many formidable problems such as workers' loyalty to the political party, multiple unions, and inter-union rivalries. In Bangladesh, trade unions are product of multi-party politics. They are more loyal to the party to which they belong and less to the organization. All these non-cooperative activities may result in decline of output and employment (Mondal, 1998);

(4) Managers underestimate the intelligence and potentials of their subordinates. They hold the view that most of the union leaders are not well-educated and trained, and consequently, they cannot meaningfully participate in the decision-making process;

(5) Managers complain that union's leaders often make unreasonable demands. They do not consider the financial ability of the organization. They are more concerned about their rights and almost indifferent to their duties and obligations, that is higher productivity;

(6) Managers make allegations against union leaders' involvement in corruption. A manager of a commercial bank says, "Union puts undue pressure on managers to get a favorable decision and even union leaders are engaged in extorting money from management". Union leaders are rated very poor in ethical and moral practice;

(7) The union alleges that managers do not treat them as equal partners of management in joint-bodies. "We are not equal partners in reality", says a union leader;

(8) Union leaders allege that a scheme of cooperative management is not given adequate publicity. This has resulted in low awareness and appreciation among workers in labor-management cooperation scheme;

(9) Union leaders also ridicule the idea of playing managers. After all, they are not paid to manage. Union leaders feel that cooperative participation is a waste of time for them, because it serves management's interest;

(10) Union leaders feel that managers may use cooperative committee as an alternative to the union. Union leaders feel that in the name of cooperation, managers may weaken the union's bargaining power; 
(11) Union leaders allege that managers are biased and unfair in their dealings with workers. They play dirty game of rule and divide with unions;

(12) Union leaders complain that their managers are very self-centered. Employers and managers regard their enterprises as their personal property and seek a higher return on their investment without due regard to the workers' well-being. For example, the minimum wage in the Ready Made Garments (RMG) sector is Taka 5,300 (\$68) per month. Employers have a tendency to monopolize the financial gains;

(13) Unions resist productivity enhancement programs when these programs become a threat to their job security. In the name of cooperation and efficiency improvement, management may reduce the number of workers;

(14) Unions may perceive that there are no adequate rewards for accepting additional responsibility. Unions claim that managers and employers monopolize almost all benefits. There is no need to extend cooperation;

(15) Another important barrier to sound employee-management cooperation is the weak communication link between management and workers' representatives and between workers' representatives and workers.

\section{How to Foster Sound Employee-Management Cooperation in Bangladesh}

Institutionalizing cooperative relationships is not an easy task. Management, workers, and union leaders must agree on a concept of cooperation, participation, and frank and open consultation for all kinds of production problems. An employee-management cooperation effort must be uniquely tailored to reflect the needs and culture of a specific organization. While the factors that are significant in the successful operation of labor-management cooperation committees differ from country to country, management, union leaders, experts, and political leaders highlighted some crucial points, which are discussed below:

(1) Without management support and commitment, cooperative labor-management schemes cannot succeed. Top management and workers must realize that industrial peace or progress lies with the cooperation between labor and management. They must believe the fact that "either cooperate or perish". Managers must provide a vision for the firms and inspire others to commit themselves to this vision;

(2) The attitudes of managers toward workers must be positive. Managers must treat their people with respect and dignity because people have a lot of positive potentials. When employees are well treated by the boss, they are likely to develop a positive attitude toward supervision and management (Luthans, 2008). In Japan, however, managers and workers see themselves as one group, and the result is that everyone is highly committed and motivated. The basic idea underlying the Japanese approach is to bring management and workers together as partners;

(3) Managers must have confidence in the people. Trust in subordinates is the foundation for delegating authority. They must set a good example of trust. A manager gets things done through people. Effective managers are increasingly being described as coaches rather than bosses. He must respect the individuality of a worker;

(4) Unions should be provided with all relevant information. The trade unions of the Toyota Company, for example, receive information about the company's financial position and production schedules. The result is a more efficient production and happier employees;

(5) Guaranteed employment security is essential to utilizing employee potential. People resist productivity improvement schemes when they feel threatened to lose jobs. This threat of losing jobs due to increased productivity is termed as soldiering by F. W. Taylor (1917), the father of scientific management. Japanese 
employees are innovative and welcome to changes because they know that their jobs are well-secured. Changes will not cause displacement. Resistance to change can slow the innovation process;

(6) Profit sharing, gain sharing, and employee stock ownership plan (ESOP) incentives can be used to motivate employees to perform better. Advocates contend that the workers extend support and cooperation to increase productivity if they are convinced that they will enjoy adequately the benefits derived from the increased cooperative efforts (Ouchi, 1981). All employees will work together toward the organization's best interest;

(7) Management must reward workers for their creative behavior. Managers must have tolerance for mistakes, make employee feel that mistakes will not be punished, focus on mistakes as learning opportunities;

(8) The manager must create a family friendly working environment. Excellent companies of USA, according to Peters and Waterman (1982), introduced flexible working schedule and this informal organizational climate may result in robust company growth;

(9) Employees would be more responsive to accept change if they participate in identifying and choosing among improvement ideas. Managers must create a climate that contributes to a free and open exchange of ideas. Union and management should jointly set productivity growth goals (Cascio, 1995; Griffin, 2000). Union leaders demand a true participation in managerial decision-making at all levels, including union representation on the board of directors. Union representation on the board is highly practiced in Germany. This practice is called self-determination;

(10) Employee-management relations or cooperation is about the interactions between workers and employers, and between their respective organizations, as influenced by government and other work-related issues. Communication lies at the very heart of manager-employee relations and the quantity and quality of communication between management and workers at the enterprise level are significant factors in establishing and maintaining harmonious industrial relations. Communication channels should ideally provide management with feedback regarding programs or policies and their implementation;

(11) Empowering employee may be a great factor for promoting effective employee-management cooperation. It adds dynamism to the employer-employee relationship by giving workers not only a voice in decision-making on matters that affect their interest and welfare, but also an opportunity to contribute creative, innovative ideas to achieve enhanced product or service quality and productivity;

(12) Politicization of trade union must be stopped in the greater interest of the country, because the inter-union rivalry has hindered the effectiveness of employee participation in cooperative activities.

\section{Conclusions}

It can be concluded that both management and workers must realize the fact that they can only meet their demand for increased profit and wage by enhancing productivity, which depends, to a large extent, on cooperative relationships between them. Without productivity improvement, organizations cannot withstand the challenge of fierce international competition, which in turn may eventually jeopardize workers and managers' jobs. Organizational survival will depend on its ability to increase productivity. Managers and workers, therefore, should forget their narrow vested interests and work together as a cohesive team for the greater interest of the organization in particular and the country in general. Both are equal partners of industrial peace and progress. They are no more enemies; rather the enemy is international competitors. Employers and union leaders have a joint responsibility for achieving joint labor-management collaboration. 


\section{References}

Akkas, M. A. (1994). How to optimize R\&D teamwork. Journal of the Cost and Management Accountant, 12(1), 25.

Akkas, M. A. (1998). Labor-management cooperation in Bangladesh. Journal of Business Studies, 19(1), 36.

Akkas, M. A. (2001a). Making a rational decision in the enterprises of Bangladesh: A critical review. Journal of Social Science Review, 20(2), 21-42.

Akkas, M. A. (2001b). Politicization of trade unionism in Bangladesh: Causes and consequences. Journal of Business Studies, 22(1), 10.

Ali, M. A., \& Shams, M. N. S. (2000). Trade unionism in Bangladesh-A survey of the impact of trade unionism on wage, employment and work environment in the manufacturing sector. The Jahangirnagarn University Review, 11(1), 27-46.

Anderson, H., Hossain, N., \& Sahota, G. S. (1991). The effect of labor laws and labor protection on employment and industrialization in Bangladesh. The Bangladesh Development Studies, 19(1), 23-35.

Cascio, W. F. (1995). Managing human resources: Quality of work life and productivity, and profit. New York: McGraw-Hill Inc.

Cooke, W. N. (1990). Labor-management cooperation. Kalamazoo, M.I.: W.E. Upjohn Institute for Employment Research.

Cooke, W. N. (1998). Factors influencing the effect of joint union-management programs on employee-supervisor relations. Industrial and Labor Relations Review, 43, 587-603.

Crane, D. P. (1992). Patterns of labor-management cooperation. Employer Responsibilities and Rights Journal, 5(4), 1-11.

Darby, L. M. (2006). Labor-management cooperation: A study of labor-management committees in Canada. Industrial Relations Centre, Queen's University, Kingston, Ontario.

Davis, K. (1990). Organizational behavior at work (10th ed.). New Delhi: McGraw-Hill Companies, Inc.

Drucker, P. F. (1994). The practice of management. New York: Harper and Brothers.

Gatchalia, G. C. (2012). Workplace cooperation and labor management council. Asian Productivity Organization, Tokyo, Japan.

Griffin, R. W. (2000). Management. Singapore: McGraw-Hill.

Kochan, T. A., Katz, H. C., \& McKersie, R. B. (1984). The transformation of American industrial relations. New York, N.Y.: Basic Books.

Kochan, T., \& Osterman, P. (1994). The mutual gains enterprise. Boston, USA: MIT Press.

Luthans, F. (2008). Organizational behavior. New Jersey: McGraw-Hill Inc.

Mondal, A. H. (1998). Trade unionism, wages and labor productivity in the manufacturing sector of Bangladesh. Research Report No. 133, BIDS, Dhaka.

Morita, A. (1982). Made in Japan. New York: McGraw-Hill.

Ouchi, W. (1981). Theory Z: How American business can meet the Japanese challenge. Reading, M.A.: Addision-Wesley.

Peters, T. J., \& Waterman, R. H. (1982). In search of excellence. New York: Harper and Row.

Pfeffer, J. (1998). The human equation: Building profits by putting people first. Boston, M.A.: Harvard Business School Press.

Taylor, F. W. (1917). The principles of scientific management. New York: Harper and Brothers.

Weihrich, H. (1996). Management excellence: Productivity through cooperation. New York: McGraw-Hill Book Company.

Weinberg, R. S. (1988). The mental advantage. Champaign, I.L.: Leisure Press. 